\title{
THE IMPACT OF THE APPLICATION OF WOOD ON THE TECHNOLOGICAL PREPARATION FOR FURNITURE MANUFACTURING
}

\author{
Petar Namichev $^{1}$, Mihail Petrovski ${ }^{2}$ \\ ${ }^{1,2}$ University Goce Delcev Shtip, Republic of North Macedonia \\ petar.namicev@ugd.edu.mk, petrovski.04@gmail.com
}

\begin{abstract}
This paper analyzes the influence of the application of wood on the technological preparation of furniture production. When it comes to furniture production the wood as a choice of material is the most used material today as it was in the past. It describes the physical and chemical properties of the wood, its technology for making furniture, as well as the influence of the choice of the type of wood on the application of furniture production. From the conducted research in furniture manufacturing companies it can be concluded that at the moment the most common wood for furniture production in North Macedonia is the beech, the second is the oak, and the third is the walnut. The technologies used to process these types of wood are up to date with world-class technology, and when economies are required, sometimes chipboard and mediapan are also used. The best type of wood for making furniture is the oak, but from the research it can be concluded that besides being less available from the beech, it is also more difficult for processing and requires different machining.
\end{abstract}

Key words: furniture, technology, wood, machines

\section{INTRODUCTION}

The best-quality furniture today is usually made of wood. The very wood with its natural properties, the aesthetic appearance and the quality it possesses is imposed as a necessary need in every home.

Historically, the wood has been widely used throughout the centuries and various movements and social orders. At the beginning furniture made of wood represented the splendor of the rich bourgeoisie.
Original Scientific Paper doi:10.5937/jouproman7-21995

In the further development of furniture, the wood became more accessible, raising to a contemporary form where wood furniture is the standard of modern living.In the future, traditional wood in its natural form will become more respected and more valuable than ever. The crafting of fine furniture and instruments, and the creation of carvings and sculpture will be elevated just that much higher on the scale of cultural respect. (R. Bruce Hoadley, 2000: 256)

The essence of how wood influences the technological preparation of furniture production lies in the analysis of the wood and all its properties, from physical, chemical and mechanical to ergonomic, wear, surface coatings, etc. Each wood has its own unique properties and defects, and having this in mind we can influence the technological preparation in order to increase productivity and reduce costs, which means that for a shorter period of time more work will be done.

The following criteria for completing suites are most frequently adopted: type of material, wood species, type of surface finish, place of use of the furniture, and the historical period in which the furniture was made or what period it refers to stylistically. (J. Smardzewski, 2015: 47) 


\begin{tabular}{lll} 
Criteria & $\begin{array}{l}\text { Manufacturers } \\
(\mathbf{n}=22)(\%)\end{array}$ & $\begin{array}{l}\text { Consumers } \\
(\mathbf{n}=125)(\%)\end{array}$ \\
\hline Cost (Price) & 9.09 & 10 \\
\hline Attractive Grain Pattern & 4.55 & 10 \\
\hline Availability & 9.09 & 0 \\
\hline Customers Demand & 31.82 & 0 \\
\hline Durability & 40.9 & 0 \\
\hline Ease of Use & 4.55 & 0 \\
\hline Density & 0 & 60 \\
\hline Colour & 0 & 20 \\
\hline Health Benefit/Hazard & 0 & 0 \\
\hline Total & 100 & 100
\end{tabular}

Table 1. Criteria for the right selection of wood for furniture production

\section{PHYSICAL AND CHEMICAL PROPERITES OF WOOD}

The most characteristic physical properties of wood are: porosity, humidity, thermal and sound conductivity, etc.

The percentage of porosity in a wood can reach up to $75 \%$. It affects the weight of the wood, the absorption of water and luster, and so on. By reducing the porosity the mechanical characteristics increase. (Josifovska, Stefanovska, 2013: 63)

Wood moisture depends on the weight of the wood itself, while the wood contains $50 \%$ of water that loses after cutting. Semi wood contains $30 \%$ moisture, dry wood up to $20 \%$ and drying about $17 \%$ moisture. Therefore, in order to reduce the moisture content of the wood, we need to fill the pores with varnishes, tar oils, linseed oil and oil paint that prevent the absorption of moisture. (Josifovska, Stefanovska, 2013: 63)

The humidity of the wood that is recommended in the exploitation of structures is the humidity that will reduce the dimensional changes to a minimum. The demand for moisture in the wood depends on the exploitation conditions and the external or internal climate. In the table below, you can see which percentage of the humidity of the wood is recommended according to the conditions.

\begin{tabular}{l|c} 
Conditions & $\begin{array}{c}\text { Percentage } \\
\text { of humidity }\end{array}$ \\
\hline In a direct contact with water & $18-20 \%$ \\
\hline For outdoor use & $13-16 \%$ \\
\hline For partially protected items & $12-15 \%$ \\
\hline For indoor use & $8-12 \%$ \\
\hline $\begin{array}{l}\text { For lamellar wood } \\
\text { with indoor use }\end{array}$ & $5-7 \%$
\end{tabular}

Table 2. Recommended percentage of humidity according to the conditions, external and internal

The thermal conductivity of the wood depends on the humidity, the volume mass and the direction of the wood fiber, and thanks to the porous structure of the wood that makes it a poor heat conductor, wood is used for the production of furniture, floors, etc.

Sound conduction is more common in coniferous species of trees, while deciduous trees have weaker sound properties.

The electrical conductivity of the wood depends on the moisture content of the wood. For example, dry wood is a bad conductor of electricity and therefore serves as an insulator. (Josifovska, Stefanovska, Spasovska, 2013: 139)

When analyzing the wood, the chemical properties are studied to give an insight into the influence of their composition on the characteristics of the material, as well as the application of the material in a particular environment and under certain conditions.

The chemical structure of the wood varies from species to kind, but is approximately $50 \%$ carbon, $42 \%$ oxygen, $6 \%$ hydrogen, $1 \%$ nitrogen and $1 \%$ other elements (calcium, sodium, magnesium, potassium, iron, manganese) by weight. The wood also contains sulfur, chlorine, silicon, phosphorus and other elements in small quantities. 


\begin{tabular}{|c|c|}
\hline Parameter & Weigh loss \\
\hline Density & $-0.18 * *$ \\
\hline Moisture content & 0.22 \\
\hline Cellulose & $0.49 *$ \\
\hline Lignin & $-0.58 * *$ \\
\hline Total phenol content & $-0.92 * *$ \\
\hline
\end{tabular}

Table 3. Correlation matrix for the degradation rates with the physical and chemical properties of the wood

$*$ Significant on $p=0.05$

$* *$

$=$ Significant on $p=0.001$

Aside from water, wood has three main components. Cellulose, a crystalline polymer derived from glucose, constitutes about 41-43\%. Next in abundance is hemicellulose, which is around $20 \%$ in deciduous trees but near $30 \%$ in conifers. It is mainly five-carbon sugars that are linked in an irregular manner, in contrast to the cellulose. Lignin is the third component at around $27 \%$ in coniferous wood vs. $23 \%$ in deciduous trees. (Boerjan, Ralph, Baucher, 2003: 519-549.)

The wood needs protection against atmospheric influences, moisture, high temperatures and pests in order to prevent the degradation of wood. Protecting the wood from moisture is done by applying lacquer paints and applying louvres whose function is to protect the wood from cracking and allow it to breathe.

During the exploitation, the wooden construction is exposed to a change in humidity then impregnation of the wood has to be carried out. Impregnation is performed before or after gluing the boards, and depending on whether the impregnation is performed before or after gluing, the choice of the type of adhesive is different.

\section{FURNITURE TECHNOLOGY}

The furniture manufacturing industry has been revolutionized over the past several decades. Today, most commercial and production furniture is created by large machinery, much of it automated and controlled by computer. The prevalence of high-tech machinery increases the accuracy and speed of manufacture, but also removes much of the craftsmanship involved. When used well,and with high-quality materials, machinescan make solid and attractive furniture.(Jagg Xaxx, Technology Used in Manufacturing Furniture, attached $27^{\text {th }}$ of April, 2019 on www.ehow.com)

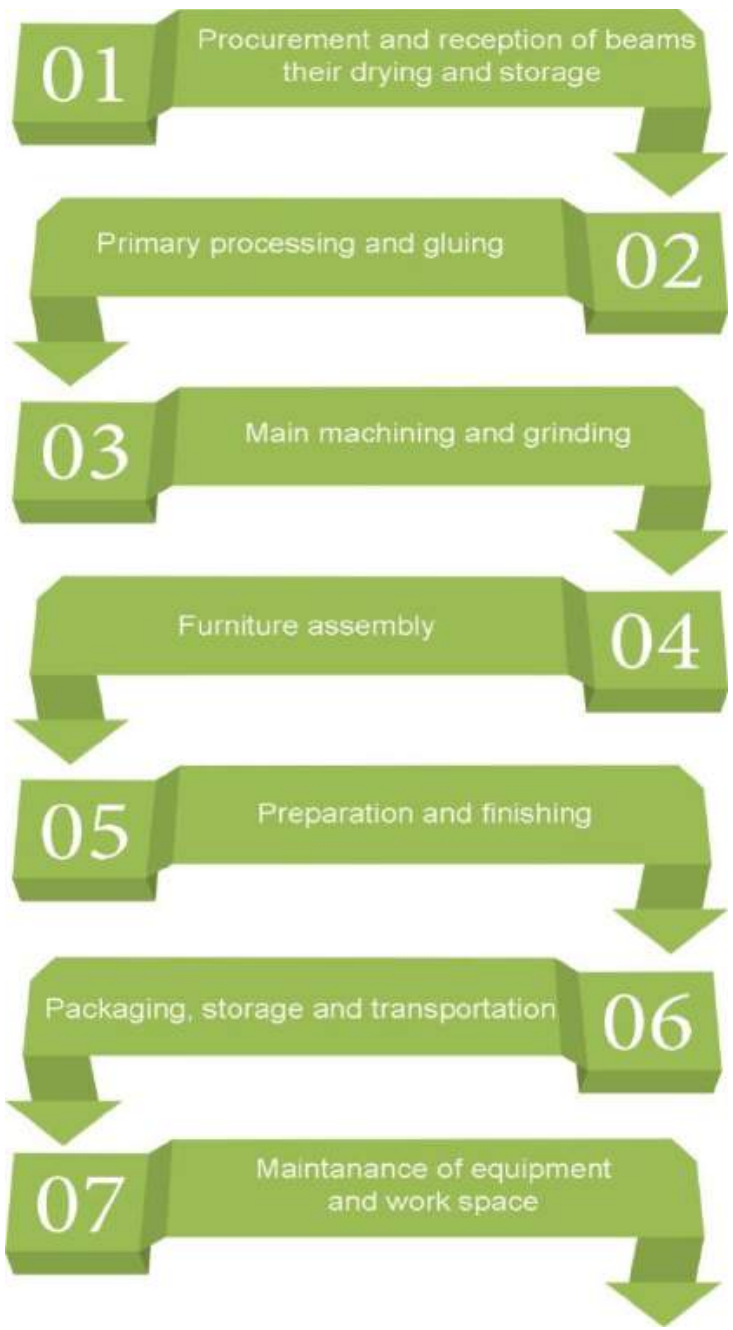

Figure 1. Operations that cover the process of producing wood furniture 
The procurement and reception of the wooden beams includes several operations before proceeding in the next process for obtaining the finished product: unloading the wooden beams, determining their quality, sorting, air (natural drying) on the beams, then drying the beams in a dryer, and finally storage in separate warehouses before the process of machining and inventory management.

The raw wood is dried by natural way or forced through a plant in special dryers. Classical (conventional) dryers, condensation and combined (represent variants of classical dryers) are the most widespread, but vacuum, microwave ovens, dryers that function on the principle of impulse extraction, etc. are also used.

Next step is primary processing which is an operation where the defects of the dried beams are removed, whereupon they are cut into prismatic shapes or veneers. This group of operations also includes longitudinal extension of the beams, resulting in long boards or slats, which also reduces the amount of generated waste and ensures better utilization of the material.

During the operation main (machining) processing, pre-processed prismatic wooden elements that are in the operation of primary processing are shaped according to the necessary dimensions for the parts of the furniture. Depending on the shape and function of the production elements of the furniture, they can cover the following machining operations: cutting, rendering, grinding and drilling. Depending on the size of the production plant and the volume of furniture production, various machines and tools are used from manual to combined, numerically controlled or carpentry machines.
After the machining and grinding finishes, the various processed and shaped pieces of furniture are merged and assembled into a finished product. The assembly usually involves the use of adhesives (natural and synthetic) in combination with other methods of binding (staple, screws, etc.). In the upholstered furniture industry, solvent adhesives are used, and in the non-upholstered furniture industry, most commonly used adhesives are (thermoplastic) or polyvinyl acetate.In most cases, the assembly operation also includes adjustment and inspection operations.

Surface finishing is the most complex and critical process for the production of one final product. The function of this procedure is that wood, as a natural material - biopolymer to protect against the harmful influence of the environment, as well as give it a certain appearance, which will make the human living space pleasant for living. Depending on the wood material, the purpose of the furniture, the technology and the method of production, there are different types of substrates and materials for surface treatment and ways of applying them.

In general, the procedure for finishing the furniture involves the application of a protective material (layer), its drying and grinding, and these processes are repeated until the desired final appearance of the product is obtained. For the surface treatment of wood, most commonly used are liquid varnishes, in which the liquid component is composed of organic solvents or water. (Olgica M., Elena A., 2015: 84)

After the finished production process, finished furniture is packed in order to protect against unplanned damage and breakage, which can occur during transport. 


\section{WOOD AT DIFFERENT TYPES OF FURNITURE}

According to the research conducted through the furniture companies, a survey was conducted with experts in the field of wood industry. An interviewing technique was used, and during the research, a freeinterview protocol was used as an instrument for data collection.

Through the realized research the following conclusions were made:

- The design influences the right selection of wood because the choice of wood is in a direct relation with the design itself, i.e the design dictates the choice of wood because certain types of wood that do not have very good elastic properties and if the design of the piece of furniture contains curved shapes, then that woodwill obviously be a bad choice for that design. This claim was agreed by all six respondents.

- The function and form are in a covalent relationship according to one of the interlocutors, while the other five interviewees agree that the form always follows the function, because when you plan to make a new piece of furniture, first thing you do is decide its function, is it going to be a piece of furniture that is used for sitting, lying, sleeping or working on? Later when it is decided what its function is going to be you move on to shaping that piece of furniture, thus confirming that the form always follows the function.

- The following table (No. 4) shows which type of wood is recommended for the use of different type of piece of furniture. For the chair is recommended beech and oak, for table is recommended beech, oak and walnut, for a closet - classic wood on the visible surfaces and plywood onthe concealed parts, for sofa is recommended beech and oak for the construction and plywood for the other parts and for kitchen elements are recommended oak or plywood.

\begin{tabular}{|l|c|}
\hline TYPE OF FURNITURE & RECOMMENDED WOOD \\
\hline Chair & Beech, oak \\
\hline Table & Beech, oak, walnut \\
\hline Closet & Wood or plywood \\
\hline Couch & Beech, oak-construction \\
\hline Kitchen elements & Oak or plywood \\
\hline
\end{tabular}

Table 4. Summarized answers to the question for which product what type of wood is recommended to be used

- One of the interviewers who has years of experience and expertise in the use of the wood advised that the most beautiful and most visible parts of a piece of furniture should always be made of the best quality wood, while the invisible parts or those who will be covering the wall side should be made of plywood or other inferior wood.

- According to the analysis from the 6 conversations I had with people that work in the wood industry the following table (No.5), we can see how much wood is used for certain parts of different pieces of furniture: 


\begin{tabular}{|c|c|}
\hline TYPE OF FURNITURE & AMOUNT OF WOOD \\
\hline Chair, std.dimensions & $0,010 \mathrm{~m} 3$ \\
\hline $\begin{array}{l}\text { Table }-2,5 \mathrm{~cm} \text { thickness } \\
\text { and } 180 \mathrm{~cm} \text { height with } \\
70 \mathrm{~cm} \text { width and legs } \\
7,5 \mathrm{~cm} \text { height with } 10 \times 10 \mathrm{~cm} \\
\text { width and length }\end{array}$ & $0,15 \mathrm{~m} 3$ \\
\hline Couch & $5 \mathrm{~cm} 3$ \\
\hline Closet - $200 \times 80 \mathrm{~cm}$ & $1 \mathrm{м} 3$ \\
\hline
\end{tabular}

Table 5. How much wood is used for different types of furniture

- When it comes to making a chair, the best choice of wood is oak, maple and mahogany (imported). The highest quality table is made of pine, fir and poplar. The best quality couch is made of oak, walnut and teak wood and the best quality kitchen elements are made of oak, maple and cherry.

\begin{tabular}{|l|l|}
\hline TYPE OF FURNITURE & $\begin{array}{l}\text { THE BEST } \\
\text { QUALITY WOOD }\end{array}$ \\
\hline Chair & 1.Oak \\
& 2.Mahogany \\
\hline Table & 3.Maple \\
\hline & 1.Pine \\
\hline Couch & 2.Fir \\
& 3.Poplar \\
\hline Kitchen elements & 1.Oak \\
\hline & 2.Walnut \\
\hline 3.Teak wood \\
1.Oak \\
\hline 2.Maple \\
3.Cherry
\end{tabular}

Table 6 . The best quality wood for different kind of furniture

- Beech is the most common wood in the Republic of North Macedonia with representation of $41 \%$, followed by oak near $16 \%$ and boron with $15 \%$ representation. $11 \%$ is the representation of the cherry and the fir is present with $9 \%$ walnut is in the last place with $5.2 \%$ representation. One of the respondents in the manufacture of furniture uses imported new types of wood from Amazon, Africa and China that are not available in our country.

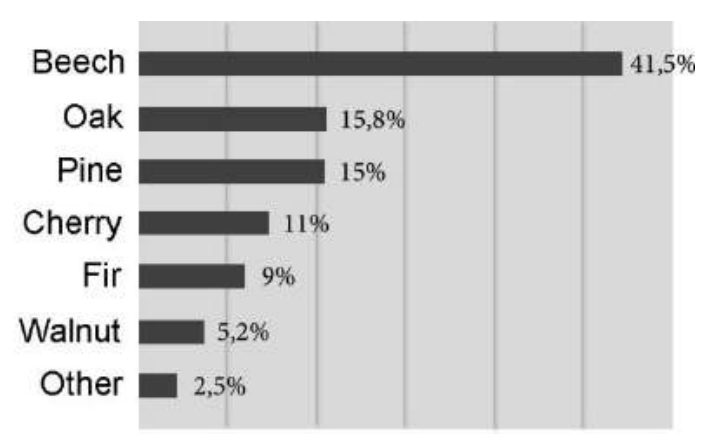

Табела 7. Most common wood in North Macedonia according to the 6 respondents

- The machines are compatible when changing the type of wood and most often the change is made for economical reasons and to increasing productivity.

- The change in the type of wood is done either due to economical reasons or when changing the mechanization, certain types of wood are more difficult to process and therefore the change in the type of wood to increase productivity is imminent.

\begin{tabular}{|c|l|c|c|c|}
\hline N. & \multicolumn{1}{|c|}{ Measured/calculated parametars } & $\begin{array}{c}\text { Drilling operation } \\
\text { with a CNC machine }\end{array}$ & $\begin{array}{c}\text { Drilling operation with } \\
\text { a traditional machine }\end{array}$ & $\begin{array}{c}\text { Differences } \\
(\%)\end{array}$ \\
\hline 1 & Operation time for one product per minute & 4.54 & 23.20 & -411 \\
\hline 2 & Number of required operations, assists & 1 & 2 & -100 \\
\hline 3 & Labor cost per hour in Euros & 4.85 & 4 & +17.5 \\
\hline 4 & Cost of labor, hour operation in Euros & 0.37 & 1.55 & -319 \\
\hline
\end{tabular}

Table 8 Difference in parametars between the $\mathrm{CNC}$ and the traditional machine 
- According to the respondents, the quality remains standard throughout the years, as no change has taken place, and until it is done, it depends on the type of wood. If the wood is inexpensive it is understood that the quality will be weaker compared to other types of wood.

- There were also table tests of the percentage of representation of component materials in different types of furniture and they are shown in the table below (n.9)

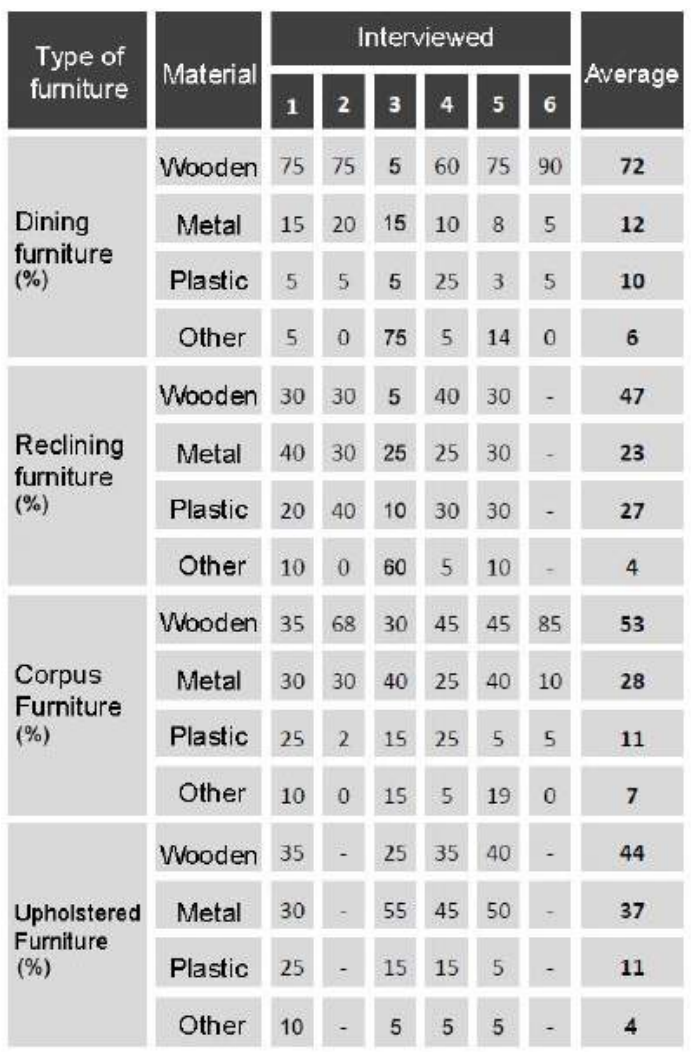

Table 9.Percentage of material representation in different types of furniture

- The proportion of wood in one chair is $69 \%$, while the remaining $31 \%$ are plastic, polyurethane, fabric, etc. In one table the share of wood is $70 \%$, kitchen elements are also $70 \%$, while with upholstered furniture it is $27 \%$. The lowest share of wood is in corpus furniture with only $5 \%$.

\begin{tabular}{|c|c|}
\hline \multicolumn{2}{|c|}{$\begin{array}{l}\text { AVERAGE COMPOSITION OF CHAIRS } \\
\text { arithmetic of } 3 \text { products }\end{array}$} \\
\hline Material & Percentage \\
\hline wood & $69 \%$ \\
\hline plastic & $10 \%$ \\
\hline polyurethane & $9 \%$ \\
\hline fabric & $3 \%$ \\
\hline packaging & $9 \%$ \\
\hline other & $1 \%$ \\
\hline \multicolumn{2}{|c|}{$\begin{array}{l}\text { AVERAGE COMPOSITION OF TABLES } \\
\text { arithmetic of } 3 \text { products }\end{array}$} \\
\hline Material & Percentage \\
\hline wood & $70 \%$ \\
\hline metal & $15 \%$ \\
\hline plastic & $1 \%$ \\
\hline packaging & $9 \%$ \\
\hline other & $5 \%$ \\
\hline \multicolumn{2}{|c|}{$\begin{array}{l}\text { AVERAGE COMPOSITION OF KITCHEN ELEMENTS } \\
\text { arithmetic of } 3 \text { products }\end{array}$} \\
\hline Material & Percentage \\
\hline wood & $70 \%$ \\
\hline metal & $20 \%$ \\
\hline plastic & $2 \%$ \\
\hline packaging & $8 \%$ \\
\hline other & $5 \%$ \\
\hline
\end{tabular}

Table 10.Percentage of representation of various materials in an average composition of furniture

\begin{tabular}{l|c|}
$\begin{array}{l}\text { AVERAGE COMPOSITION OF UPHOLSTERY } \\
\text { FURNITURE, arithmetic of } 3 \text { products }\end{array}$ \\
\hline \multicolumn{1}{|c|}{ Material } & Percentage \\
\hline wood & $27 \%$ \\
\hline metal & $31 \%$ \\
\hline plastic & $17 \%$ \\
\hline fabric & $15 \%$ \\
\hline packaging & $9 \%$ \\
\hline other & $1 \%$ \\
\hline $\begin{array}{l}\text { AVERAGE COMPOSITION OF CORPUS FURNITURE } \\
\text { arithmetic of 3 products }\end{array}$ & \\
\hline \multicolumn{1}{|c|}{ Material } & Percentage \\
\hline wood & $5 \%$ \\
\hline metal & $15 \%$ \\
\hline plastic & $1 \%$ \\
\hline plywood & $69 \%$ \\
\hline packaging & $9 \%$ \\
\hline other & $1 \%$ \\
\hline
\end{tabular}

Table 11. Percentage of representation of various materials in an average composition of furniture 


\section{CONCLUSION}

The wood with its aesthetics, excellent physical and chemical properties and the enticing appearance has always been the number one in the selection of material for furniture production. The tree itself carries its own beauty, except that with a natural character it brings freshness into a home whether it will be through the use of the floor, walls, ceiling or furniture production. Technological preparation is one of the stages that are implemented in the production of furniture, while others are prepared for raw materials, their drying, refinement, design concept, assembly, etc.If the tree has strong physical properties it means that it is hard to work with, which means it needs special technological preparation and compatible machines that can process it. From this we conclude that the influence of the application of wood on the technological preparation in furniture production is big. For the simple reason that every type of wood carries with it some specific properties that need to be processed in detail through analysis and data processing until the machine processing, assembly, packaging, etc.

In fact, the technological preparation is done so that the wood receives the best treatment with the smallest waste and the most efficient use of the quality part of the wood in order to obtain a quality final product.

Today, many employers who are engaged in the production of wood furniture are concerned with the supply of wood, as in North Macedonia as well as in the world too. This means that in the future it is imperative to improve the management of forests.

In the past, the price of the tree could not bear the cost of intensive forest management, but today with the value of the plywood and the mediapan, we have a complete change of the image. As the environment, forests and environmental impacts need to meet our needs in the future, so must technology itself too. The goal of each technologist should be to improve the products to meet all human needs, through a competitive price and a change in the resources of the wood.

Wood has a future at all levels of use. For our forests will give us not only a backbone resource for large-scale commodities but also the semiprecious jewels for our wood-crafting endeavors. Historians tell us we have passed through the stone and bronze and iron ages. We now hear mention of space age. But it may well be that yet ahead is a new age of wood... for those who understand it. (R. Bruce Hoadley, 2000: 256).

\section{REFERENCES}

- Andonova, E., Andonovski, T(2013): Finalna obrabotka na drvoto - Skopje: Ministerstvo za obrazovanie i nauka na R.S. Makedonija

- Nojfert E. (1981): Arhitektonsko projektovanje, Gradjevinska knjiga, Beograd

- Teischinger, Barbu, Dunky, Harper, Jungmeier, Militz, Musso, Petutschnigg, Pizzi, Wieland, Young (2010) „Processing Technologies for the Forest and Biobased Products Industries" Salzburg University of Applied Sciences, Kuchl/Austria, 2010

- JosifovskaR., StefanovskaS., SpasovskaV. (2013), GRADEZNI MATERIJALI:Gradeznogeodetskastruka; arhitektonski tehnicar; Skopje, Ministerstvo za obrazovanie I nauka na R. S. Makedonija

- Manevska, Simonovska, Mitrikeska (2012), MASINI I ALATI ZA MEBEL I ENTERIER: Sumarsko - drvoprerabotuvacka struka; tehnicar za mebel I enterier;Skopje, Ministerstvo za obrazovanie I nauka na R.S. Makedonija

- R. Bruce Hoadley (2000), UNDERSTANDING WOOD - a craftman's guide to wood technology 
- Joseph Aronson (2000), The Encyclopedia of Furniture - third edition - completely revisited

- Theodore Wegner, Kenneth E. Skog, Peter J. Ince, and Charles J. Michler (2010), Uses and Desirable Properties of Wood in the $21^{\text {st }}$ Century

- Slavid, R. (2012) Out of the woods - the creation of 12 hardwood chairs- Washington: UBM Client Solutionsfor The American HardwoodExport Council

- Smardzewski, J. (2015) Furniture Design Spinger International Publishing Switzerland.

- Josifovska R., StefanovskaS., SpasovskaV. „GRADEZNI MATERIJALI I KONSTRUKCII”, Gradezno-geodetska struka; gradezen tehnicar-Skopje 2013, Ministerstvo za obrazovanie i nauka na R.S. Makedonija

- W. Boerjan; J. Ralph; M. Baucher (June 2003). "Lignin biosynthesis". Annu. Rev. Plant Biol. 54 (1): $\quad 519$ 549. doi: 10.1146/annurev.arplant.54.031902.13 $\underline{4938}$ 